\section{Acknowledgement of Referees}

As a refereed journal, the success of Politics and the Life Sciences depends on the generosity of a great many scholars who donate their time and expertise to review manuscripts. The scholars listed below reviewed one or more manuscripts for $P L S$ in 1995 . We extend our sincere thanks for their vital contribution to the journal's mission.

$\begin{array}{ll}\text { Bruce Ambuel } & \text { Michael Moodie } \\ \text { Larry Arnhart } & \text { Francis Moran } \\ \text { Carol Barner-Barry } & \text { Stephen Morse } \\ \text { Robert Blank } & \text { Ellen Moskowitz } \\ \text { Mary Anne Bobinski } & \text { Barry Noon } \\ \text { Christopher Boehm } & \text { Graham Pearson } \\ \text { Andrea Bonnicksen } & \text { Herbert Perkins } \\ \text { Jeffrey Burkhardt } & \text { Jerrold Post } \\ \text { Lawrence Busch } & \text { Laura Purdy } \\ \text { Ira Carmen } & \text { John Robertson } \\ \text { Ellen Wright Clayton } & \text { Barbara Rosenberg } \\ \text { William R. Cline } & \text { Marc Howard Ross } \\ \text { Robert Cook-Deegan } & \text { Mark Rushefsky } \\ \text { Christine Day } & \text { Nancy Segal } \\ \text { Paul Ekman } & \text { R. Paul Shaw } \\ \text { Robin Fox } & \text { Daniel Simberloff } \\ \text { Henry Glick } & \text { Donald Songer } \\ \text { David Goodman } & \text { Robert Sprinkle } \\ \text { William Green } & \text { Jessica Eve Stern } \\ \text { Kathi Hanna } & \text { Susan Strange } \\ \text { Chris Hillyer } & \text { John Strate } \\ \text { Michael Holmes } & \text { Carson Strong } \\ \text { Martha Holstein } & \text { Pierre van den Berghe } \\ \text { Donald Horowitz } & \text { Tatu Vanhanen } \\ \text { Martin Kenney } & \text { Norman Vig } \\ \text { Sheldon Krimsky } & \text { Ian Vine } \\ \text { Sanford Lakoff } & \text { Paul Wapner } \\ \text { John Loomis } & \text { Stephen Wasby } \\ \text { Joseph Losco } & \text { David Webber } \\ \text { Roger Masters } & \text { Dorothy Wertz } \\ \text { Deborah Mathieu } & \text { Elliott White } \\ \text { Gary Melton } & \text { Yuwa Wong } \\ \text { Marque-Luisa Miringoff } & \text { Gene Wood } \\ \text { Mary Maxwell } & \text { Alan Zelicoff } \\ \text { Janna Merrick } & \text { Raymond Zilinskas } \\ \text { Robert Mitchell } & \\ & \\ & \end{array}$

\section{PLS Issue Dates}

Beginning with this issue, publication dates of Politics and the Life Sciences will be March and September rather than February and August. For the purposes of the editorial offices, these new dates are a better fit with the cycles of the U.S. academic year.

\section{APLS Annual Meeting}

The 1996 annual meeting of the Association for Politics and the Life Sciences will be held in conjunction with the meeting of the American Political Science Association, August 28 to September 1, 1996 at the San Francisco Hilton and Towers Hotel in San Francisco, California. The program chair-for a program that is now complete-is Ira Carmen of the University of Illinois. For additional information about the APLS meeting, contact Executive Director James N. Schubert, Department of Political Science, Northern Illinois University, DeKalb, IL 60115, USA; tel: (815) 7539675; e-mail: T70JNS1@MVS.CSO.NIU.EDU. For information about registration and lodging, contact the American Political Science Association, 1527 New Hampshire Ave., N.W., Washington, DC 20036, USA; tel: (202) 483-2512; fax (202) 483-2657.

\section{APLS Graduate Student Paper Award}

The Association for Politics and the Life Sciences annually awards a prize for the best paper by a graduate student on a topic that relates the life sciences to the study of politics or public policy. Graduate student papers using empirical or theoretical approaches that address relevant problems are eligible for consideration. Papers coauthored with faculty members are not eligible. The award for the best graduate student paper is a cash prize of US\$500. The selected paper will also be included in the program at the APLS annual meeting and considered for publication in Politics and the Life Sciences. Graduate students should submit three copies of their manuscript, accompanied by a written endorsement by a faculty sponsor (who need not be from the institution at which the student is formally enrolled, and who may be a scholar in any discipline). Manuscripts should be submitted if possible by March 15, 1996, when assessment will begin, but they will be accepted until May 1. Submissions should be sent to Andrea L. Bonnicksen, Department of Political 
Science, Northern Illinois University, DeKalb, IL 60115 , USA; tel: (815) 753-7039; fax (815) 753-6302; e-mail: ALBCORN@NIU.EDU.

\section{NEH-NSF Summer Institute on Human Nature}

A six-week NEH/NSF Summer Institute on "Human Nature: Integrating Nature and Nurture" will take place at Dartmouth College from July 8 to August 16, 1996. This summer institute is co-sponsored by the Gruter Institute for Law and Behavioral Science, with additional cooperation from the Rockefeller Center for the Social Sciences at Dartmouth.

"Human Nature: Integrating Nature and Nurture" is designed for faculty who are planning or now offering an interdisciplinary course integrating recent research in the life sciences with some field or fields in the social sciences or humanities. The institute will be co-directed by Roger D. Masters (Department of Government, Dartmouth) and Robert Perlman, M.D. (Department of Pediatrics and Division of the Biological Sciences, University of Chicago). The program will include such distinguished visiting lecturers as Evelyn Fox Keller (MIT), Robert Trivers (Rutgers), Frans de Waal (Emory), Jeanne Altmann (Chicago), Jean Bethke Elshtain (Chicago), Michael Gazzaniga (University of California, Davis), Michael T. McGuire (UCLA), Lionel Tiger (Rutgers), Jane Lancaster (University of New Mexico), Robert Frank (Comell), and other leading scholars.

The institute is limited to 25 participants. In selecting participants, preference will be given to teams of two (or rarely three) applicants from different scholarly fields who plan to teach an undergraduate course together. Under the terms of the NEH/NSF grant, those selected will receive a stipend of US\$250 per week in addition to a stipend for transportation, room, and board. Government regulations require attendance for the full six weeks of the seminar. By the end of the seminar, participants will be expected to have worked out the syllabus they propose to offer at their own institution.

Applications should include a curriculum vitae, names of two references, and information concerning relevant courses previously taught or now planned. The deadline for applications is March 1, 1996, but late applications may be considered on a space-available basis. For further information or to apply, write Roger D. Masters, Department of Government, Silsby 6108, Dartmouth College, Hanover, NH 03755, USA; tel: (603) 646-2153; fax (603) 646-2152; e-mail: ROGER.D.MASTERS@DARTMOUTH.EDU.

\section{Biological Perspectives in the Social Sciences}

The third annual faculty seminar on "Biological Perspectives in the Social Sciences" was held at Dartmouth College in August, 1995. The NEH/NSF Summer Institute on "Human Nature: Integrating Nature and Nurture" (see previous announcement) replaces the "Biological Perspectives" seminar for 1996, but the seminar will again be offered in 1997.

\section{Biology and Politics Committee of IPSA}

Research Committee \#12 (Biology and Politics) of the International Political Science Association (IPSA) wishes to expand its mailing list to include more scholars interested in the connection between politics and biology. The committee's scope includes the effects of evolutionary and physiological forces on political behavior and institutions, as well as the policy implications of knowledge from the life sciences. Albert Somit is President of the committee. Those not already on the list who would like to be added should send name, address, and e-mail address to Steven A. Peterson, Division of Social Sciences, 1 Saxon Drive, Alfred University, Alfred, NY 14802, USA; fax: (607) 871-2114; e-mail: FPETERSON@BIGVAX.ALFRED.EDU.

\section{APLS and Research Committee \#12 Meeting}

The Association for Politics and the Life Sciences and Research Committee \#12 (Biology and Politics) of the International Political Science Association plan to co-sponsor (with the College of Liberal Arts and Sciences of Alfred University) a meeting at Alfred University from July 25 to 27, 1996. Program organizers are Albert Somit, James N. Schubert, and Steven A. Peterson. The subject will be "Current Research in Biopolitics." The organizers encourage paper proposals in two areas-biopolicy and biobehavioral research. They also welcome participation of others who choose to serve as discussants or simply attend the meeting. Proposals to present papers or serve as a discussant should be received by March 15 .

Transportation will be arranged from the Rochester, NY airport to Alfred (and back again). Room and board will run approximately US $\$ 40$ per day if one prefers to stay in a dorm or about $\$ 90$ per day if one chooses to stay at the Saxon Inn, the university's bed and breakfast. Proceedings of the conference will be edited and then published in book form as part of the JAI Press series, "Research in Biopolitics." In addition, the European Sociobiological Society (ESS) will meet in Alfred immediately before the joint IPSA-APLS meeting. The theme will be "Sociobiology and Politics." Those interested in attending that meeting as well should indicate their interest and appropriate materials will be forwarded. Proposals and requests for additional information should be directed to Steven A. Peterson, Division of Social Sciences, 1 Saxon Drive, Alfred University, Alfred, NY 14802, USA; tel: (607) 871-2215; fax: (607) 871-2114; e-mail: FPETERSON@BIGVAX.ALFRED.EDU. 


\section{Meeting of European Sociobiological Society}

The nineteenth annual meeting of the European Sociobiological Society (ESS) will be held July 22-25, 1996 at Alfred University in Alfred, New York, USA. The meeting will immediately precede a special meeting on "Current Research in Biopolitics" co-sponsored by the International Political Science Association's Research Committee \#12 and the Association for Politics and the Life Sciences (see previous announcement).

The theme of the conference will be "Sociobiology and Politics." This theme is to be defined broadly enough to include such issues as exercise of power, dominance, leadership in societies (including nonhuman) from an evolutionary perspective; gender differences in political behavior; war and other forms of political violence, etc. A number of rooms in dorms will be available (at about US $\$ 18.00$ per person per night. The deadline for registration is May 31 , 1996; the deadline for abstracts is June 30. Registration, abstracts, and requests for additional information should be directed to Steven A. Peterson, Division of Social Sciences, 1 Saxon Drive, Alfred University, Alfred, NY 14802, USA; tel: (607) 871-2215; fax: (607) 871-2114; e-mail: FPETERSON@BIGVAX.ALFRED.EDU.

\section{Human Behavior and Evolution Society Meeting}

The 1996 annual meeting of the Human Behavior and Evolution Society (HBES) will be held June 26-30, 1996 at Northwestern University in Evanston, Illinois. HBES is a multidisciplinary society that studies human affairs from a Darwinian perspective. Keynote speaker for the meeting will be Edward O. Wilson.

The deadline for abstracts for proposed presentations is March 15, 1996. For information about submitting a proposal, contact Michael Bailey, Department of Psychology, Northwestern University, 303A Swift Hall, Evanston, IL 60208-2710, USA; e-mail: JMBAILEY@NWU.EDU. For information on registration and housing, contact William Irons, Department of Anthropology, Northwestern University, 1810 Hinman Avenue, Evanston, IL 60208-1310, USA.

\section{Intensive Bioethics Course XXII}

The twenty-second annual Intensive Bioethics Course, sponsored by the Kennedy Institute of Ethics at Georgetown University, will be held from Sunday evening, June 2, through Saturday noon, June 8, 1996. The course is an in-depth study of ethical theory and the application of ethical principles to selected problems in health care and biomedical research. Limited to 200 participants, it is directed primarily toward physicians, nurses, and policymakers in the health care field.

Lecture topics have traditionally included theories of normative ethics; the principles of beneficence and nonmaleficence, autonomy, and justice; virtue-based ethics; the ethic of care; health care allocation; informed consent; bioethics and the law; death and dying; and human gene therapy.

Faculty include Tom L. Beauchamp, Alisa L. Carse, James F. Childress, Ruth R. Faden, Patricia King, Margaret Olivia Little, Edmund D. Pellegrino, Madison Powers, Robert M. Veatch, LeRoy Walters, and Kevin Wm. Wildes.

The course fee is US\$1400. This does not include the costs of lodging, dinner on Monday through Thursday evenings, nor any graduate credit fees. For further information and applications, contact Marc Favreau, Course Coordinator, Kennedy Institute of Ethics, Georgetown University, Washington, DC 20057, USA; tel: (202) 687-6771; fax: (202) 687-8089; e-mail: FAVREAUM@GUVAX. GEORGETOWN.EDU.

\section{Clinical Ethics Seminars}

CEREC Center of Southeast Florida will offer two clinical ethics seminars in 1996. The first, "Ethical Issues in Renal Dialysis and Kidney Transplantation," will be held from April 26 to 28, 1996. The second, "Ethical Issues in the Care of Incompetent Patients," will be held from August 23 to 25, 1996. Both seminars will take place at the Rolling Hills Hotel and Golf Resort, Ft. Lauderdale, Florida, USA. CEREC (Clinical Ethics Research, Education, and Consultation) Seminars combine lectures by renowned bioethicists with participant presentations and parallel sessions on clinical cases. To foster an atmosphere of interdisciplinary dialogue and critical discussion, only 45 participants will be admitted. All plenary lectures will be in English; parallel sessions may be held in other languages (Spanish, Italian, French, German, or Dutch). For more information, contact Dr. Jos V.M. Welie, CEREC Center, P.O. Box 292932, Ft. Lauderdale, FL 33329, USA; tel/fax: 1-305-424-9304; e-mail: JWELIE@BCFREENET.SEFLIN.LIB.FL.US.

\section{Meeting of the International Society for Human Ethology}

The thirteenth biennial conference of the International Society for Human Ethology (ISHE) will take place August 5-10, 1996 in Vienna, Austria. For information about paper proposals (which are due by May 1), contact Alain Schmitt at the address below. For registration and other information, contact Karl Grammer, Ludwig-Boltzmann-Institut for Urban Ethology, c/o Inst. für Humanbiologie, Universität Wien, Althanstr. 14, 1090 Vienna, Austria; tel: (Europe) (0043) (1) 31-336-1253; fax: (0043) (1) 31-336-788; e-mail: KARL GRAMMER@UNIVIE.AC.AT. Consult the World Wide Web at HTTP://EVOLUTION.HUMB.UNIVIE. AC. AT for more on the conference and on ISHE 


\section{Fulbright Scholar Awards}

Fulbright scholar awards are again available to offer U.S. faculty, professionals, teachers, and students the opportunity to conduct research, teach, or study abroad and to make a contribution to the growth of mutual understanding among countries and individuals.

Awards range from two months to a full academic year, and assignments are flexible. Openings exist in almost every area of the arts and humanities, social sciences, natural and applied sciences, and professional fields. Fulbright recipients include academic administrators, independent scholars, artists, and professionals from the private and public sectors.

Eligibility requirements are U.S. citizenship and a Ph.D. (or comparable professional qualifications). University or college teaching experience is expected for lecturing awards, and language skills are needed for some countries, although most lecturing assignments are in English. Funding is provided by the U.S. Information Agency and cooperating governments and host institutions abroad.

The deadline for lecturing and research grants for 1997 98 is August 1, 1996. Other deadlines for special programs include distinguished Fulbright Chairs in Western Europe and Canada (May 1) and Fulbright seminars for international education and academic administrator awards (November 1). For further information and application materials, contact the USIA Fulbright Senior Scholar Program, Council for International Exchange of Scholars, 3007 Tilden Street, N.W., Suite 5M, Box GNEWS, Washington, DC 200083009, USA; tel: (202) 686-7877; Web page: HTTP://WWW.CIES.ORG/; e-mail (application requests only): CIES1@CIESNET.CIES.ORG.

\section{Donations for PLS}

We gratefully acknowledge a recent US\$500 gift from a donor who wishes to remain anonymous. Such generosity is important for the journal's continued growth and development. As both an international and interdisciplinary journal, $P L S$ is expensive to produce. Subscription and membership fees cover only a small part of our costs. If you would like to make a donation to $P L S$, please make your check pay able to the LSSU Foundation and specify that your gift is for support of the editorial offices of Politics and the Life Sciences. Donations should be sent to the LSSU Foundation, Lake Superior State University, 844 North Campus Court, Sault Ste. Marie, MI 49783, USA. We will be pleased to acknowledge your generosity in this section of the journal. 